\title{
RESENSI
}

\section{ACADEMIC ARCHIVES: MANAGING THE NEXT GENERATION OF COLLEGE AND UNIVERSITY ARCHIVES, RECORDS, AND SPECIAL COLLECTIONS}

\section{Suprayitno, S.I.P.}

PNS Kementerian Ketenagakerjaan Republik Indonesia, Jakarta (manager.records@gmail.com)

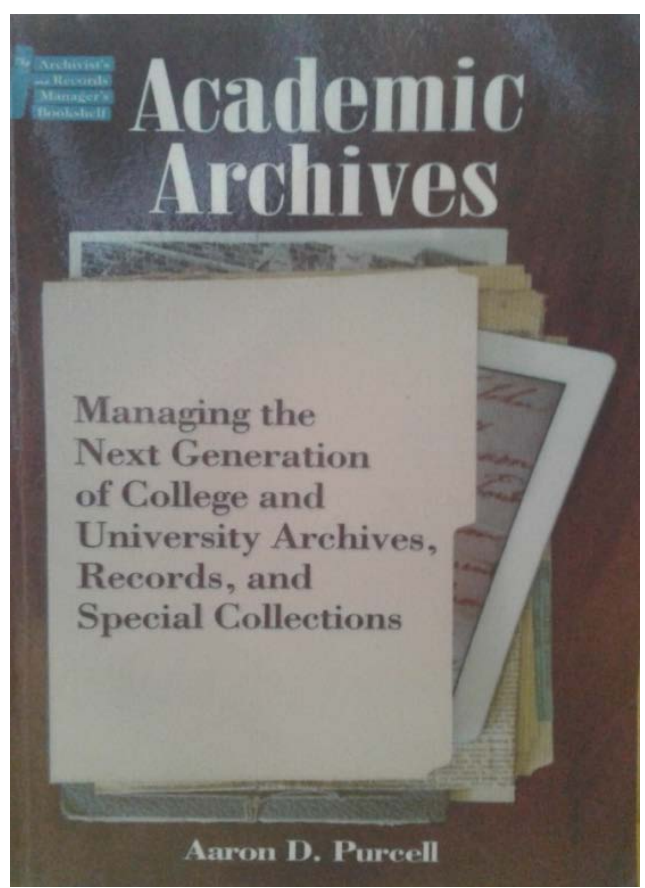

Judul

Penulis

Penerbit

Tahun

Halaman

ISBN
: Academic Archives: Managing Next Generation of College And University Archives, Records, and Special Collections

: Aaron D. Purcell

: Neal-Schuman, Chicago

: 2012

: 277

: 978-1-55570-769-9 
Sampai tahun 2008, sudah ada 5 buah bibliografi kearsipan yang membahas tentang Arsip Universitas/Perguruan Tinggi (University Archives) yaitu: College and University Archives: Selected Readings dari SAA (1979); The Management of College and University Archives karangan William J. Maher (1992); Varsity Letters: Documenting Modern Colleges and Universities karangan Helen Samuels (1992); College and University Archives: Readings in Theory and Practice karangan Christopher Prom dan Ellen Swain; dan "Campus Case Studies” dari SAA (2008). Dari Kelima referensi di atas, yang membahas secara rinci tentang manajemen arsip perguruan tinggi adalah Maher (1992) dan Samuels (1992). Maher mendefinisikan arsip universitas secara eksklusif dengan berangkat pada makna ontologis arsip itu sendiri yang official, sementara Samuels lebih menekankan pada dokumentasi total di lingkungan perguruan tinggi. Konteks zaman ketika kedua pengarang ini menyusun buku adalah saat belum dikenalnya "Archives 2.0" yaitu media arsip sudah tidak kertas lagi, melainkan web, dan fokus utamanya adalah pengguna, teknologi, standardisasi, advokasi, assessment, engagement, dan openness (hm. 245).

Istilah Archives 2.0 dipengaruhi oleh penggunaan aplikasi-aplikasi berbasis Web 2.0 dan social media, seperti blogs, Facebooks, Twitter, dan Flickr. Archives 2.0 menekankan pada openness dan flexibility. Arsiparis era Archives 2.0 dituntut lebih mengutamakan pengguna, bukan arsip itu sendiri, serta peka pada potensi penggunaan teknologi untuk berbagi (sharing) koleksi, berinteraksi dengan pengguna, serta melakukan perbaikan efisiensi internal. Jangkauan pendekatan kearsipan Archives 2.0 meliputi preservasi arsip-arsip dinamis (records) yang diciptakan oleh bloggers, serta penggunaan tools berbasis 2.0 lainnya.
Arsiparis Archives 2.0 dituntut lebih aktif dalam komunitasnya, bukan pasif; ikut terlibat menginterpretasikan koleksinya, bukan sekadar menjadi penjaga (custodian) netral; serta melakukan advokasi terhadap program dan profesi kearsipan.

Berangkat dari tantangan Archives 2.0 inilah, Aaron D. Purcell mendefinisikan arsip maupun arsiparis perguruan tinggi (Purcell memilih istilah arsip akademik dan arsiparis akademik) lebih inklusif. Bila definisi university archives sebelumnya mengacu pada program arsip universitas yang mengumpulkan, melestarikan dan menyediakan akses materi arsip untuk mendokumentasikan sejarah universitasnya, bidang arsip akademik jauh lebih ekspansif dan kompleks. Dalam buku ini Purcell menempatkan arsip akademik di bawah perpustakaan akademik dengan mengintegrasikan sistem informasi dari berbagai repositori di lingkungan perguruan tinggi. Purcell menyarankan bahwa arsip universitas dimerger dengan bagian koleksi khusus yang ada di perpustakaan pusat universitas. Begitu juga istilah arsiparis akademik tidak lagi sebatas archivists yang hanya mengelola arsip statis di perguruan tinggi, melainkan lebih inklusif meliputi profesi-profesi lainnya seperti records manager,pustakawan koleksi khusus, reference archivist, manuscript processor, kurator koleksi, dan para ahli buku-buku langka (hlm. 21).

Purcell menggunakan istilah archives, records, dan special collections pada awalnya sesuai dengan definisi tradisional, namun khusus untuk special collections diartikan lebih inklusif. Archives (arsip statis) merupakan arsiparsip dinamis (records) yang terpilih dan dinilai karena bernilai guna historis yang ada di lingkungan akademik/perguruan tinggi. Records (arsip dinamis) dalam buku ini tidak didefinisikan secara jelas, namun selalu dikaitkan dengan records 
management yang dapat diartikan sebagai rekaman informasi yang official atau dalam rangka kegiatan di lingkungan perguruan tinggi. Pada penjelasan tentang special collection, Purcell awalnya menyitir definisi tradisional dalam bidang kepustakawanan, yakni sebagai koleksikoleksi di perpustakaan selain koleksi utama (buku, terbitan berkala, publikasi ilmiah, dan semacamnya). Beberapa yang termasuk dalam koleksi khusus (special collections) dalam perpustakaan meliputi buku-buku langka, foto-foto historis, serta koleksi audio visual.

Dengan perkembangan Web 2.0 yang menuntut openness and engagement, Purcell mendefinisi special collections tidak sebatas rare books, tetapi juga naskah, arsip statis (archives), arsip dinamis (records), koleksi berbasis subjek, serta arsip audio-visual (Hlm. 63). Di sinilah, tampak bahwa Purcell ingin menekankan kolaborasi arsip (baik archives maupun records) dengan koleksi khusus dalam payung Perpustakaan Perguruan Tinggi.

Buku ini membahas big-picture, isuisu pekerjaan praktis arsiparis akademik dan mengelola next generation programprogram arsip akademik. Buku Academic Archives ini tidak fokus pada arsip universitas semata, tetapi mengkonseptualisasikan arsip akademik lebih luas, dengan fokus tertentu pada penggabungan (merger) unit kerja di perpustakaan perguruan tinggi, seperti unit koleksi khusus. Tema-tema dalam buku ini meliputi pilihan karier dalam arsip akademik, bekerja dengan profesional informasi lainnya dalam perpustakaan akademik, pengintegrasian fungsi-fungsi manajemen arsip dinamis, membangun koleksi dengan kerja sama para pendonor, pameran materi unik ke khalayak umum, pendekatan pengolahan dan pengelolaan koleksi organisasi, peluang-peluang digital, peranan arsiparis pada perpustakaan akademik abad ke-21, serta mendefinisikan apa itu arsiparis akademik.

Buku ini terdiri atas 3 bagian. Pada bagian pertama, Archives and the Academic Environment terdiri atas 3 bab (Bab 1-3). Bab 1 membahas tentang pengantar dan definisi arsip akademik, serta peluang dan tantangan arsiparis akademik. Purcell melihat tantangan arsiparis akademik dari data $\mathrm{A} * \mathrm{CENSUS}$ di mana ternyata dari hasil survei tersebut jumlah responden yang menjawab, jumlah arsiparis akademik porsinya cukup banyak (36\%) di samping arsiparis pemerintahan (32\%). Dalam survei tersebut juga dijelaskan bahwa mayoritas arsiparis akademik mempunyai harapan menjadi bagian aktif dalam komunitas ilmiah, disertai dengan adanya pengembangan profesi dan pendidikan lebih lanjut.

Bab 2 membahas tren-tren terkini dalam perpustakaan akademik dan bagaimana perkembangan TIK telah mendefinisikan ulang peran perpustakaan universitas di seputar kehidupan mahasiswa, fakultas dan peneliti. Pemahaman akan perpustakaan akademik menjadi sangat penting dalam memahami arsip akademik. Bab 3 lebih fokus pada koleksi khusus, seperti koleksi naskah (manuskrip), arsip institusional, bahan-bahan cetakan, dsb. Koleksi khusus saat ini telah menjadi inti pekerjaan arsiparis akademik karena di antaranya berfungsi sebagai tempat instruksional inovatif, public program, event, dan pameran, serta poin sentral untuk riset ilmiah.

Bagian kedua, Building and Updating an Academic Archives Program terdiri atas 6 bab.(Bab 4-9). Bab 4 membahas pendekatan praktis dalam menjaga dan memelihara misi serta menuliskan visi arsip akademik. Arsiparis akademik yang sukses harus menunjukkan kepemimpinan yang luas, mengelola dan berbagi sumber daya, selalu mengikuti perkembangan, mengidentifikasi stakeholders, serta 
mentargetkan pengguna koleksi dan jasanya.

Bab 5 berbicara tentang manajemen arsip dinamis. Program manajemen arsip dinamis adalah bagian krusial dalam arsip akademik. Arsiparis dituntut untuk dapat bekerjasama dengan para unit kerja di lingkungan perguruan tinggi dalam menjamin keutuhan arsipnya karena hulu dari arsip akademik adalah pengelolaan arsip dinamis yang praktiknya ada di berbagai unit-unit kerja.

Kebijakan koleksi yang kuat bisa membendung masuknya koleksi-koleksi yang semestinya bukan core dari khazanah arsip akademik. Pada Bab 6 dijelaskan mengapa dan bagaimana arsiparis akademik menentukan cakupan koleksinya serta sumber daya internal dan eksternal yang mungkin menjadi target akuisisinya. Sumber-sumber ini dapat mendokumentasikan berbagai fungsi kampus yang lebih luas, beserta sejarahnya, serta topik-topik historis nonkampus lainnya yang mendukung misi lembaga, kurikulum, serta program arsipnya.

Bahasan mengenai pengolahan dan pengelolaan koleksi ada pada Bab 7. Bahasan ini meliputi tahap-tahap accessioning, prosedur pengolahan koleksi secara umum, dan cara arsiparis akademik mengelola koleksi dan ruangnya. Aktivitas “di balik layar” ini juga meliputi kegiatan preservasi dan konservasi, sekuritas, disaster planning, dan pembuatan sarana temu-balik arsip.

Layanan publik dan penelitian dibahas pada Bab 8. Bahasannya antara lain meliputi pendefinisian ulang rujukan, classroom instruction, interaksi virtual, proses penelitian, pameran dan event, serta outreach dan advokasi.

Bab 9 membahas tentang digital frontiers dan tantangan elektronis terhadap arsip akademik. Mudahnya akses informasi secara elektronik mengharuskan arsiparis akademik beradaptasi dengan pergeseran dan keusangan informasi. Kemampuan arsiparis akademik dalam melek TIK menjadi tantangan dan peluang dalam pelayanan publik dan outreach.

Pada bagian terakhir, The Future of Academic Archives, hanya terdiri atas 1 bab (Bab 10). Bab ini meninjau ulang tren-tren yang sedang terjadi di arsip akademik dan menggambarkan masa depan pada bidang-bidang garapan arsip akademik. Perubahan teknologi, kebutuhan riset, dan peranan perpustakaan akademik di lingkungan kampus adalah faktor signifikan dalam memahami tren-tren mendatang. Seperti pada judul buku ini, ada kata next generation, buku ini berbicara tentang masa depan. Arsip akademik saat ini lebih dari sekadar repositori sejarah institusi dan arsip-arsip ofisial. Misi dari arsip akademik telah meluas meliputi pengumpulan berbagai format dan bidang penelitian, serta menjangkau kalangan peneliti yang lebih luas dan menuntut arsiparis akademik berperan aktif melayani kebutuhan informasi komunitas kampus. Generasi mendatang program arsip akademik akan dibangun berdasarkan kemajuan teknologi, koleksi born-digital, kemitraan kolaboratif yang berbagi sumberdaya, serta skill arsiparis profesional dengan pengalaman dan pelatihan yang lebih luas.

Nilai-nilai arsiparis akademik generasi mendatang adalah:

1. Colaborators, not cooperators

2. Technical specialists, not generalists

3. Entrepreneurs, not participants

4. Teachers, not instructors

5. Activists, not promoters

6. Measuring outcomes, not statistics

7. Looking outward more than inward (hlm. 246).

Bila dilihat dari jumlah halamannya (277 hlm.), buku ini tidak terlalu tebal, tetapi isinya padat. Buku ini layak dibaca oleh arsiparis dan pustakawan di lingkungan perguruang tinggi secara khusus. Khusus untuk arsiparis 
perguruan tinggi, buku ini sekaligus menjadi tantangan tersendiri. Bila dikaitkan dengan kondisi Indonesia, di mana tren arsip perguruan tinggi baru muncul beberapa tahun yang lalu, dan kulturnya masih dipengaruhi kearsipan ala pemerintahan pada umumnya, buku ini bisa menjadi pemantik untuk adaptif terhadap perkembangan teknologi informasi dan komunikasi (TIK). Bila rekan serumpun kita, pustakawan perguruan tinggi sudah lama bergaul dengan tren-tren Library 2.0, sudah siapkah arsiparis perguruan tinggi beradaptasi dengan Archives 2.0? 